\title{
Identification of the objective function for optimization of a Seasonal Thermal Energy Storage system
}

\author{
J. Milewski, L. Szablowski \& W. Bujalski \\ Institute of Heat Engineering, Warsaw University of Technology, Poland
}

\begin{abstract}
The paper presents a proposed objective function for the operation of a Seasonal Thermal Energy Storage system. The proposed function is based on technologicaleconomic assumptions. The mathematical models of the main elements of the system were built and used for choosing the optimal system design. Based on the chosen design point and by using the models, the simulation of the operation of the whole system was done for randomly generated outside temperatures. The proposed methodology and obtained relationships can be readily used for control purposes, constituting Model Predicted Control (MPC).
\end{abstract}

\section{Introduction}

Rising fuel prices and increasing electricity consumption are driving research into more efficient electricity and heat generation sources [1]. Energy used for space and domestic water heating constitutes $1 / 3$ of the total energy used in industrialized countries like Poland. Fossil fuel consumption of and emissions may be reduced by using solar-based technologies. For electricity generation, solar energy may be used directly (PV panels) or indirectly utilizing biofuels [2-4] applying, for example, fuel cell technology which additionally features high efficiency due to the direct transformation of chemical energy into electricity [5-12]. However, the largest market for solar energy is now connected with the absorption of solar radiation into heat up media that are flowing through solar collectors.

The heating of water by solar collectors is currently a competitive solution compared to other technologies, but it is limited by solar radiation intensity, which is low in winter when heat is mainly needed. Heat storage for heating purposes 
appears justified for systems in which the solar energy share exceeds $20 \%$. To minimize heating costs and develop an efficient structure for the generation-storage system, both the design point and the off-design conditions should be optimized. This paper seeks to determine the objective function for this optimization.

\section{Identification of the objective function for optimization of a Seasonal Thermal Energy Storage system}

\subsection{Objective function coefficients}

Selected coefficients to be used in the determined objective function are presented in the Table 1. They may vary depending on the season, location (country) and local conditions. The cost of natural gas supplied to the central heating boiler was calculated assuming an efficiency level of $80 \%$ and a fuel tariff according to [13]: w-5 (gas) and E-1A (transmission) from PGNiG S.A. (in total EUR0.33/ $\mathrm{Nm}^{3}$ ) for $\mathrm{LCV}$ of $35 \mathrm{MJ} / \mathrm{Nm}^{3}$.

Table 1: Parameters for the objective function of the optimization process.

\begin{tabular}{|c|c|c|}
\hline Parameter & Value* & Remark \\
\hline $\begin{array}{l}k_{N G}, \\
\text { EUR/GJ }\end{array}$ & 12 & cost of the natural gas fed to the heating boiler \\
\hline $\begin{array}{l}k_{\text {Power }}, \\
\text { EUR/GJ }\end{array}$ & 44 & cost of electricity supplied to the heat pump \\
\hline $\begin{array}{l}k_{\text {Subcooling }} \\
\text { EUR/GJ }\end{array}$ & $k_{N G}$ & $\begin{array}{l}\text { cost of heat supply to the heat storage by a gas } \\
\text { boiler/coal boiler/municipal heating grid/and } \\
\text { heat pump }\end{array}$ \\
\hline $\begin{array}{l}k_{\text {Overload }}, \\
\text { EUR/GJ }\end{array}$ & 6.0 & $\begin{array}{l}\text { cost of heat losses, storage fully charged when } \\
\text { the balance of heat generation from the solar } \\
\text { collectors and the demand is positive }\end{array}$ \\
\hline
\end{tabular}

*for exchange rate EUR/PLN=4.2

The cost of electricity for the heat pump was taken from [14] - one-zone tariff C11 ("Simplest for your business") of RWE Poland S.A. (EUR0.16/kWh). The cost of heat losses when the store is fully charged and hence increased heat production compared to consumer heat demand was calculated for flat KS2000 TP AC solar collectors by Hewalex [15]. The net price of this device is EUR151.04 per $\mathrm{m}^{2}$ of working surface. The working life of solar collectors was assumed to vary between 15 and 25 years [16]. The cost of heat losses was 
calculated on the conservative assumption that the collectors would be in operation for 15 years. All the above costs and the other parameters and results mentioned in this article assume a EUR/PLN exchange rate of EUR 1 equals PLN 4.20.

\subsection{Heat demand}

The consumer heat demand profile was correlated with the mean outside temperature by a directly proportional relationship:

$$
Q=k \cdot\left(21-T_{\text {outside }}\right)
$$

where: $k$-proportionality constant;

The proportionality constant was tailored to the mean yearly heat demand equal to the energy needed for heating a surface area of $110 \mathrm{kWh} / \mathrm{m}^{2}$ [17].

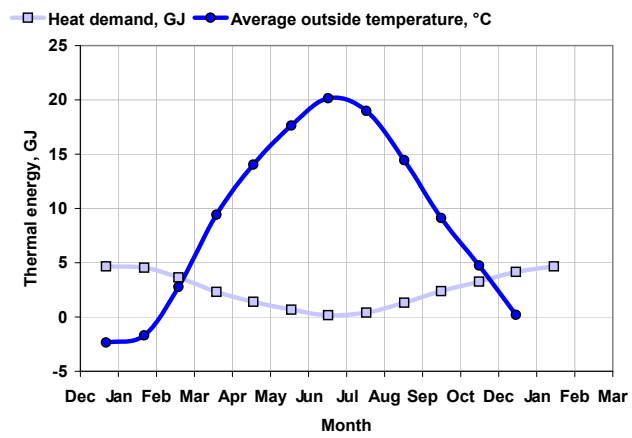

Figure 1: Outside temperature variations and heat demand.

\subsection{Heat generation in solar collectors}

The technical specification of a flat solar collector, KS2000 TP AC made by Hewalex, was used for calculations.

The efficiency of the solar collector is determined according to the following relationship [15]:

$$
\eta=\eta_{0}-\frac{A_{1} \cdot \Delta T}{E_{g}}-\frac{A_{2} \cdot \Delta T^{2}}{E_{g}}
$$

where: $\eta_{0}$-optical efficiency, $\Delta T$-temperature difference between the absorber and the surroundings, $E_{g}$-insolation.

This model was selected due to its low price compared to the vacuum model. The absorber was made from an aluminum plate of increased thickness compared to the copper plates that are typically used, hence similar features were obtained at a lower price. 


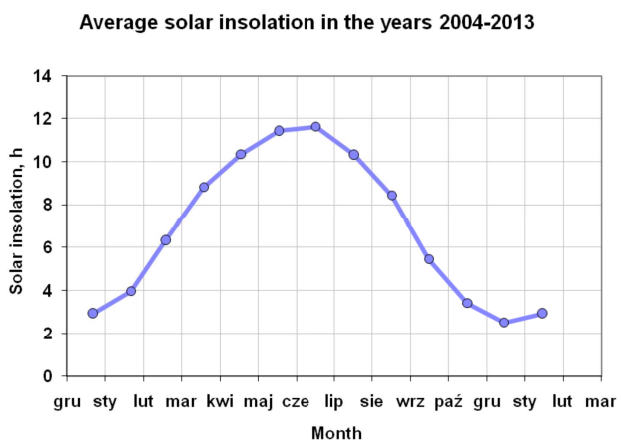

Figure 2: Average sunshine duration for Warsaw in the period 2004-2013.

Using the statistics on hours of sunshine for Warsaw (1,600 h/a) and collector efficiency, total heat generation of $1.7 \mathrm{GJ} / \mathrm{m}^{2}$ and its profile were obtained.

\subsection{Selection of the storage size and collector area}

Using the determined objective function, the requisite dimensions of the units for developing the optimal structure while maintaining design conditions were specified. For reference, the heated area was assumed to be $100 \mathrm{~m}^{2}$.

Table 2: Design parameters during optimization.

\begin{tabular}{lr}
\hline Parameter & Value \\
\hline Heated area, $\mathrm{m}^{2}$ & 100 \\
Solar collector area, $\mathrm{m}^{2}$ & 19 \\
Storage volume, $\mathrm{m}^{3}$ & 88 \\
Value of the objective function in the design point, EUR/a & 15 \\
\hline
\end{tabular}

The optimization shows the optimum area of solar collectors, storage volume and load distribution in the units (see Fig. 2).

In Fig. 3 the forecast storage temperature variations for the design point and the respective outside temperature profile are presented.

Fig. 4 shows the heat generated by respective system units in order to fulfill the energy demand for the design conditions. Negative values signify heat supplied for storage.

The objective function is EUR15/a (for $100 \mathrm{~m}^{2}$ ) for the design conditions. Every component, divided into months, is presented in Fig. 5. The largest cost is the 


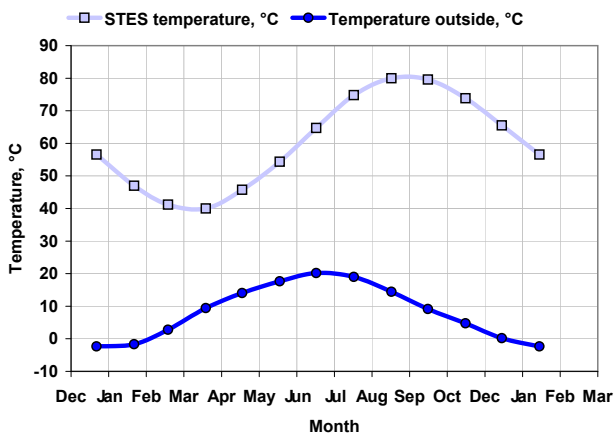

Figure 3: Temperature variations in the accumulator for the design conditions.

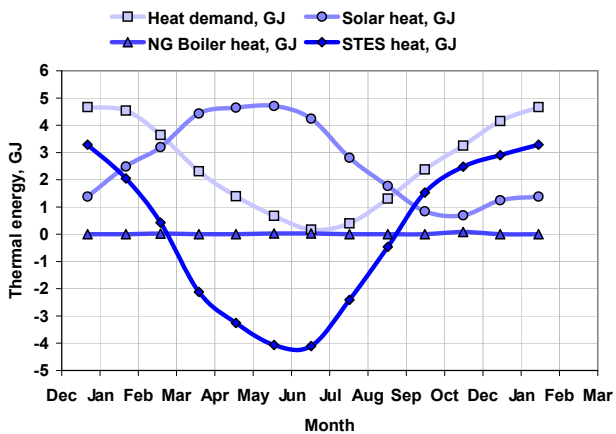

Figure 4: Heat amount generated by each units for the design point.

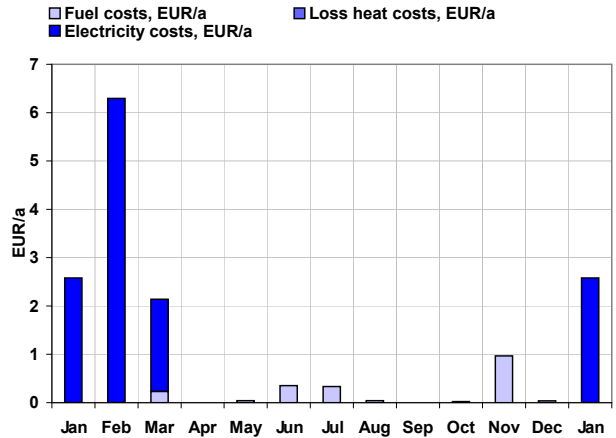

Figure 5: Components of the goal function for the design conditions, $K=$ EUR15/a.

electricity used by the heat pump when the storage water temperature-is too low for the heating network (which was assumed to be $60^{\circ} \mathrm{C}$ ). 


\subsection{Optimal system management in off-design operation conditions}

Heat storage operations may differ in reality from the design conditions (hot winter/cold summer etc.), hence it is necessary to systematically adjust the parameters. For this reason, a demand prediction was used to carry out a storage operation optimization for a given time horizon (e.g. a 12 month period). The following limitations apply:

- maximum temperature of water in storage: $80^{\circ} \mathrm{C}$

- minimum allowable temperature of water in storage: $40^{\circ} \mathrm{C}$.

After the result of optimization of the heat load on storage is obtained for 12 months, the store is managed according to the upgraded strategy for the next month and subsequently, the system is re-optimized.

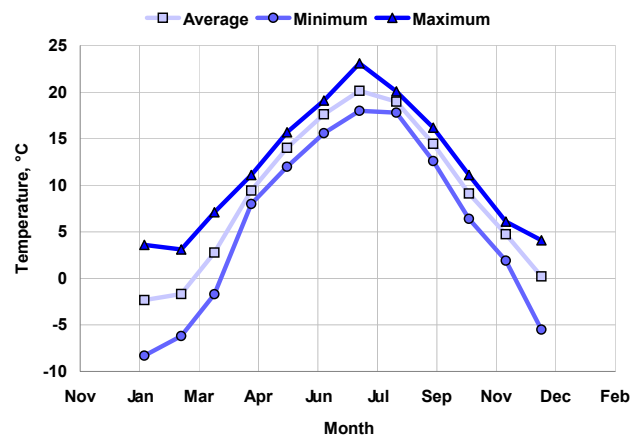

Figure 6: Average temperatures for Warsaw in the period 2004-2013.

The principle parameters that influence the system operation variations is the ambient temperature, as it affects both the consumer heat demand profile and the heat losses from the accumulator to the surroundings. Fig. 6 shows the average monthly temperatures during 10 years for Warsaw and it shows significant variations in average winter temperatures.

The system optimization result is also affected by utility prices (mainly natural gas and electricity).

Simulation results of the system operation for two different weather scenarios (see Fig. 6) are presented in the Table 3 and in Fig. 7. During a cold year, most of the costs are generated by the natural gas boiler, which mainly heats up the storage water to the same level as at the beginning of the year. On the other hand, during a warm year, the main cost is generated by the unused heat from the solar collectors. The difference in stored heat after 12 months is non-zero only for the simulation, as it is a non-optimized value as in the design variants and is the operational outcome of each month. 
Table 3: Optimal objective function values for the analyzed cases and the function components.

\begin{tabular}{lrrrr}
\hline Component & $\begin{array}{r}\text { Design } \\
\text { condi- } \\
\text { tions }\end{array}$ & $\begin{array}{r}\text { Cold } \\
\text { year }\end{array}$ & $\begin{array}{r}\text { Warm } \\
\text { year }\end{array}$ & $\begin{array}{r}\text { Simu- } \\
\text { lation }\end{array}$ \\
\hline Objective function value, EUR/a & 15 & 97 & 48 & 34 \\
Fuel cost, EUR/a & 2 & 84 & 0 & 24 \\
Cost of unused collector & 0 & 0 & 36 & 0 \\
generated heat, EUR/a & 13 & 10 & 12 & 12 \\
Electricity cost, EUR/a & 0 & 0 & 0 & -2 \\
Cost of heat stored year by year, & & & & \\
$\Delta K_{\text {HeatStorage }}$, EUR/a & & & & \\
\hline
\end{tabular}

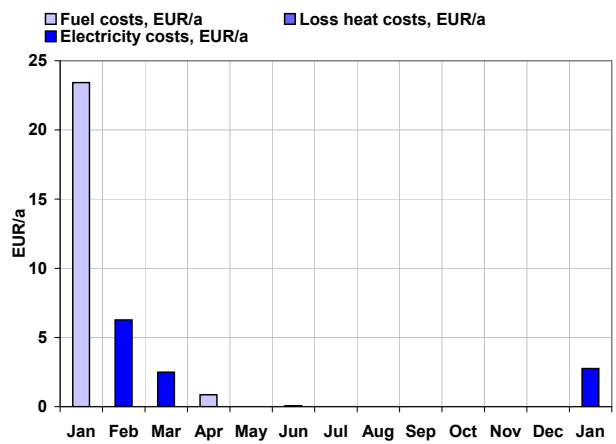

Figure 7: Simulated values of each objective function component for every month, $K=113$ EUR/a.

Fig. 8 presents heat generation values for each unit that were obtained during simulation. It should be noted that negative values for the natural gas boiler correspond to the heat that was not extracted from the solar collectors.

\section{Analysis of the obtained results}

Based on the developed system model, a simulation was performed of its operations during a 12 month period. The ambient temperature was randomly taken from the range given in Fig. 6. Optimization was conducted after each month for a time horizon equal to the next 12 months. 


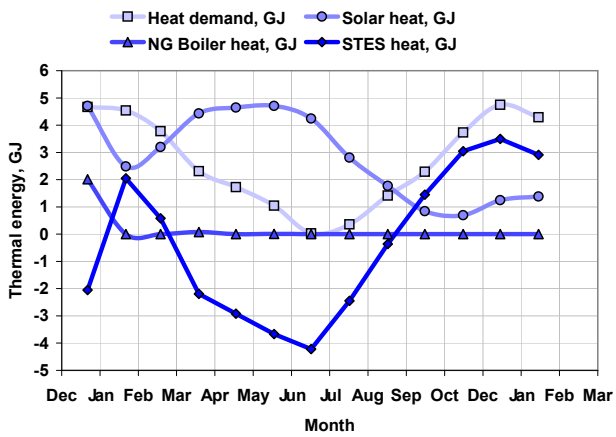

Figure 8: Simulated values of heat produced by each unit of the system, negative values for the natural gas boiler signify heat not extracted from the solar collectors.

For the analyzed cases, a 1-month-long time step and optimization horizon equal to 12 months were used. In reality, shorter time steps could be applied (week, day, hour, ... ) giving even better results.

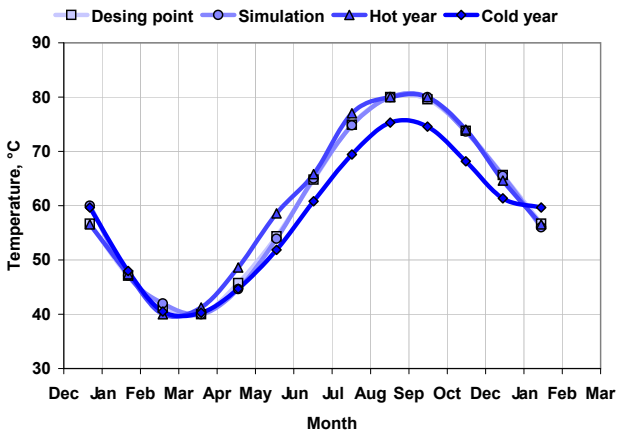

Figure 9: Storage temperature variations for the analyzed cases.

The simulated water temperatures of the heat storage were presented in Fig. 9. It is conspicuous that the simulation is significantly correlated with the design point and fits in between two extreme variants (warm and cold years).

In Fig. 10 the change of predicted objective function after each month is presented. The first month concerns initiation from design conditions and it is visible that the storage was not at the optimal point (the predicted objective function at the level of $100 \mathrm{EUR} / \mathrm{a})$. Nevertheless, optimization led to a very fast improvement of the parameter-at the following point close to the design-point value. In the following 11 months the predicted objective function varied at a very low level, giving at the end results that were lower than expected. 


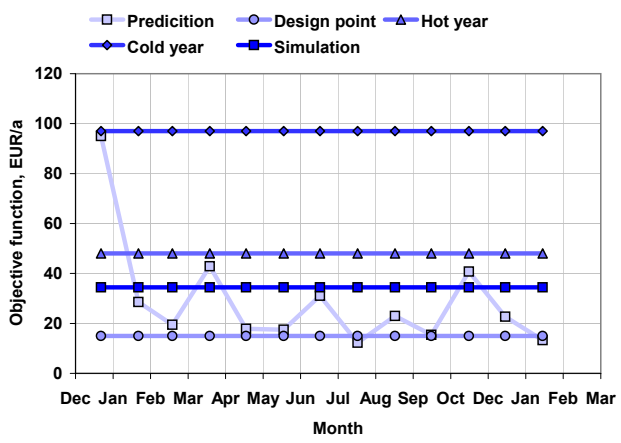

Figure 10: Values of the objective function for the analyzed cases.

\section{Summary}

The paper presents a concept of the objective function for the optimization of seasonal thermal energy storage operation. Based on the literature data the optimization horizon and possible errors (weather and demand) occurring during prediction were determined.

The proposed objective function is based on technological-economic assumptions, its main coefficients were determined for Polish conditions. Models (mostly linear) were developed of primary system elements such as:

- heat consumers,

- heat storage,

- solar collectors,

- heat pump.

They were used to optimize the principle design parameters of the system:

- solar collector area: 19/100 $\mathrm{m}^{2}$,

- storage volume: $88 \mathrm{~m}^{2} / 100 \mathrm{~m}^{2}$.

The ratio of storage volume to solar collector area that was obtained is $4 \mathrm{~m}^{3} / \mathrm{m}^{2}$, which is twice the ratio used in real applications. This may indicate that installations are currently constructed according to different criteria than proposed here (where the construction cost for the store is not taken into consideration). At the obtained design point the annual cost of heating an area of $100 \mathrm{~m}^{2}$ is EUR 15 .

Based on the developed models and the selected design point of the system, a simulation of the system in operation was performed for randomly generated average temperatures every month. During the calculations, the operation of the store was optimized in the time-horizon of the following 12 months. In the simulated conditions, the cost of heating the same area was twice that of the design point.

The main cost components are the costs of the fuel and of the electricity that has to be supplied to the heat pump; there are practically no losses due to non-extracted heat from the solar collectors. 
The proposed approach and relationships developed may be readily utilized for controlling this kind of system using MPC. It should be noted that the selected time step (1 month) made it impossible to investigate storage operation in a week/day mode, which could take place as spring turns into summer. This will be a topic of further research.

\section{Acknowledgement}

The project was funded by the National Science Centre allocated on the basis of decision number DEC-2012/07/B/ST8/03937.

\section{References}

[1] Bartela, L. \& Kotowicz, J., Analysis of operation of the gas turbine in a poligeneration combined cycle. Archives of Thermodynamics, 34(4), pp. 137-159, 2013.

[2] Guerra, C., Lanzini, A., Leone, P., Santarelli, M. \& Beretta, D., Experimental study of dry reforming of biogas in a tubular anode-supported solid oxide fuel cell. International Journal of Hydrogen Energy, 38(25), pp. 10559-10566, 2013.

[3] Kupecki, J., Jewulski, J. \& Badyda, K., Comparative study of biogas and dme fed micro-chp system with solid oxide fuel cell. Applied Mechanics and Materials, 267, pp. 53-56, 2013.

[4] Sánchez, D., Monje, B., Chacartegui, R. \& Campanari, S., Potential of molten carbonate fuel cells to enhance the performance of chp plants in sewage treatment facilities. International Journal of Hydrogen Energy, 38(1), pp. 394-405, 2013.

[5] Bakalis, D. \& Stamatis, A., Incorporating available micro gas turbines and fuel cell: Matching considerations and performance evaluation. Applied Energy, 103, pp. 607-617, 2013.

[6] Chacartegui, R., Monje, B., Sánchez, D., Becerra, J. \& Campanari, S., Molten carbonate fuel cell: Towards negative emissions in wastewater treatment chp plants. International Journal of Greenhouse Gas Control, 19, pp. 453-461, 2013.

[7] Jannelli, E., Minutillo, M. \& Perna, A., Analyzing microcogeneration systems based on lt-pemfc and ht-pemfc by energy balances. Applied Energy, 108, pp. 82-91, 2013.

[8] McLarty, D., Brouwer, J. \& Samuelsen, S., Hybrid fuel cell gas turbine system design and optimization. Journal of Fuel Cell Science and Technology, 10(4), 2013.

[9] Qian, J., Tao, Z., Xiao, J., Jiang, G. \& Liu, W., Performance improvement of ceria-based solid oxide fuel cells with yttria-stabilized zirconia as an electronic blocking layer by pulsed laser deposition. International Journal of Hydrogen Energy, 38(5), pp. 2407-2412, 2013. 
[10] Sieniutycz, S. \& Jezowski, J., Energy Optimization in Process Systems and Fuel Cells, 2013.

[11] Wang, S.B., Wu, C.F., Liu, S.F. \& Yuan, P., Performance optimization and selection of operating parameters for a solid oxide fuel cell stack. Journal of Fuel Cell Science and Technology, 10(6), 2013.

[12] Wang, W., Li, H. \& Wang, X.F., Analyses of part-load control modes and their performance of a sofc/mgt hybrid power system. Dalian Ligong Daxue Xuebao/Journal of Dalian University of Technology, 53(5), pp. 653-658, 2013.

[13] PGNiG S.A., http://www.pgnig.pl/.

[14] RWE Polska S.A., http://www.rwe.pl.

[15] Hewalex Sp. z o.o. Sp.k., http://www.hewalex.pl/.

[16] Fan, J., Chen, Z., Furbo, S., Perers, B. \& Karlsson, B., Efficiency and lifetime of solar collectors for solar heating plants. ISES Solar World Congress 2009, Johannesburg, South Africa, pp. 331-340, 2009.

[17] Dz.u. 75, poz. 690 z dnia 12.04.2002 z późniejszymi zmianami, 2002. 